\title{
34. The effects of disappointment, melancholy and pain of love on the characters in Mehmet Rauf's novels ${ }^{1}$
}

Filiz FERHATOĞLU2

APA: Ferhatoğlu, F. (2021). The effects of disappointment, melancholy and pain of love on the characters in Mehmet Rauf's novels. RumeliDE Dil ve Edebiyat Araştırmaları Dergisi, (24), 619630. DOI: 10.29000/rumelide.995372.

\begin{abstract}
In the works of the writers of the Servet-i Fünûn Era, besides the nature of sensitivity, emotionality, introversion, pessimism, and melancholy are most used factors concerned the plot and character due to the political and social conditions of the period, their sensitive disposition, and the influences of major trends and the works of Western writers they follow and take as an example. In the thirteen of Mehmet Rauf's sixteen novels the idea of falling in love, indicators of experiences of love-bond and its psychological qualities aftermath are handled as fundamental problematics. Mehmet Rauf's expression of distinctive features of melancholy which are similar to the works of Servet-i Fünûn Literature are evident when the male characters well scrutinized. In Mehmet Rauf's novels, it can be observed that the tenderness brought by love and the pain of love, and these manifestations mostly conveyed by the male characters struggling with delirium, pessimism, and melancholy. The woman in love is the element that psychologically wears out the male character and puts him into fever, and it is considered to be responsible for all his mood. On the other hand, female characters portrayed as the consummate sad women and this female affliction appears in the embodiment of sickness when they encounter a physical contact by the male character unexpectedly. In this study, the psychological and physical effects of disappointment, melancholy and pain of love of male and female characters are evaluated in Mehmet Rauf's novels Garâm-ı Şebâb, Ferdâ-yı Garâm, September, The History of A Love, Heart of a Young Girl, Carnation and Jasmine, and The Last Star.
\end{abstract}

Keywords: Mehmet Rauf, novel, Servet-i Fünûn Literature, melancholy

\section{Mehmet Rauf'un romanlarında hayal kırıklı̆̆ı, melankoli ve aşk acısının kahramanlar üzerindeki etkisi}

$\ddot{\mathbf{O} z}$

Servet-i Fünûn Dönemi yazarlarının eserlerinde hem dönemin siyasi ve sosyal şartları hem hassas mizaçları gereği hem de takip ettikleri ve örnek aldıkları Batılı yazarların eserlerinin etkisiyle hassasiyet, duygusallık, içe kapalılık, karamsarlık ve melankoli yoğun bir şekilde görülmektedir. Mehmet Rauf'un on altı romanından on üç tanesinde aşk, aşkın ortaya çıkışı, aşkın yaşanış, biçimi, aşkın bitiminde yaşananlar temel sorunsal olarak işlenmiştir. Mehmet Raufun Servet-i Fünûn Edebiyatı'nın melankolik, duyguları ve buhranları ortaya koyan ürünlerinden etkilendiği eserlerinde erkek kahramanlar incelendiğinde açıkça görülmektedir. Mehmet Rauf'un romanlarında içerisinde genellikle aşk ve aşk acısının getirdiği hassasiyet ve sonrasında çoğunlukla erkek kahramanın yoğun

This article was produced from the PhD thesis titled “Women in the Works of Mehmet Rauf” prepared by Filiz Ferhatoğlu and supervised by Prof. Dr. Murat Koç at Marmara University, Institute of Turkic Studies, Department of Turkish Language and Literature, Modern Turkish Literature Program.

2 Research Assistant Dr., Istanbul University, Research Institute of Turkology, Department of Turkish Language and Literature (İstanbul, Turkey), filizfer@istanbul.edu.tr, ORCID: oooo-ooo1-6111-9548 [Araştırma makalesi, Makale kayıt tarihi: 08.07.2021-kabul tarihi: 20.09.2021; DOI: 10.29000/rumelide.995372]

Adres | Address

RumeliDE Dil ve Edebiyat Araştırmalar Dergisi $\quad$ RumeliDE Journal of Language and Literature Studies Osmanağa Mahallesi, Mürver Çiçeği Sokak, No:14/8 Osmanağa Mahallesi, Mürver Çiçeği Sokak, No:14/8

Kadıköy - İSTANBUL / TÜRKIYE 34714 Kadıköy - ISTANBUL / TURKEY 34714 e-posta: editor@rumelide.com e-mail: editor@rumelide.com, tel: +90 505 7958124, +90 2167730616 phone: +90 505 7958124, +90 2167730616 
bir humma, karamsarlık ve melankoli ile boğuştuğu fark edilmektedir. Âşık olunan kadın, erkek kahramanı psikolojik olarak yıpratan ve hummalar içine atan unsurdur ve tüm bu ruh hâlinin müsebbibi sayılmaktadır. Bununla birlikte kadın kahramanlar ise erkek kahraman tarafından beklemedikleri bir anda fizikî bir temasla karşılaştıklarında birdenbire hastalanmaktadırlar. Bu çalışmada Mehmet Rauf'un Garâm-ı Şebâb, Ferdâ-yı Garâm, Eylül, Bir Aşkın Tarihi, Genç Kız Kalbi, Karanfil ve Yasemin ve Son Yıldız romanlarında hayal kırıklığı, melankoli ve aşk acısının kahramanlar üzerindeki psikolojik ve fiziksel etkileri değerlendirilmiştir.

Anahtar kelimeler: Mehmet Rauf, roman, Servet-i Fünûn Dönemi Türk Edebiyatı, melankoli

\section{Introduction}

In the literature of the Servet-i Fünûn, which was dominated by an individual sensitivity, two names stand out among the authors who wrote prose: Halit Ziya and Mehmet Rauf. Halit Ziya's first novel, Sefile, was serialized in the newspaper Hizmet. His serialized novels and stories were published as a complete works under the name of "Little Books". The Last Leaves of a Memorandum (Bir Muhturanın Son Yaprakları) is the first published work of this complete works. Aşk-ı Memnu, which was published after joining the Servet-i Fünûn literary community and shown as one of the most important works of Turkish literature, was serialized in Servet-i Fünûn journal between 28 Kanun-i sani 1314 [9 February 1899]-4 May 1316 [17 May 1900]. Halit Ziya, has a prominent place in the authorship of Mehmet Rauf, who is an another Servet-i Fünûn prose writer. His story "Fallen (Düşmüş)" which he sent to Halit Ziya, was published in the newspaper Hizmet and became the first published story of Mehmet Rauf. His novel Garâm-ı Şebâb was also serialized in İkdam, one of the distinguished newspapers of the period. His fame, which he gained with his novels, stories and especially prose poems, was disreputed by his pornographic novel named The Story of A Lily (Bir Zambağın Hikâyesi), which he published anonymously in 1910 .

It is seen that Mehmet Rauf, who gives great importance to human psychology, deals with the subjects of love and women in his novels, stories, plays, prose poems. Concepts such as sensitivity, melancholy, sheltering in dreams by escaping from reality, sadness, and the suffering brought by love, seen in the Turkish literature of the Servet-i Fünûn period, also emerge in Mehmet Rauf's works. Especially the effect of love on human psychology, male-female relations, types of love, sexuality, betrayal and the expectations of women and men from marriage are among the main topics seen in his works. The main fundamental problem of thirteen of Mehmet Rauf's sixteen novels is love and accordingly the idea of falling in love, indicators of experiences of love-bond and its psychological qualities aftermath. Love asserts itself not as a secondary element in Mehmet Rauf's novels, but as a primary element that directs the course of events.

The perception of Mehmet Rauf on love is a profound emotion that argue into itself with betrayal, torment, pessimism and even madness. The main male character is constantly suffering on account of women's betrayal, their natural tendency to engage in betrayal.

The disappointments of the characters who glorify love, the morbid feelings they fall into, the state of melancholy, sadness and grief, and some physiological disorders caused by the pain they experience appear to us in his novels called Garâm-ı Şebâb, Ferdâ-yı Garâm, September (Eylül), The History of A Love (Bir Aşkın Tarihi), Heart of a Young Girl (Genç Kız Kalbi), Carnation and Jasmine (Karanfil ve Yasemin), and The Last Star novels (Son Ylldz).

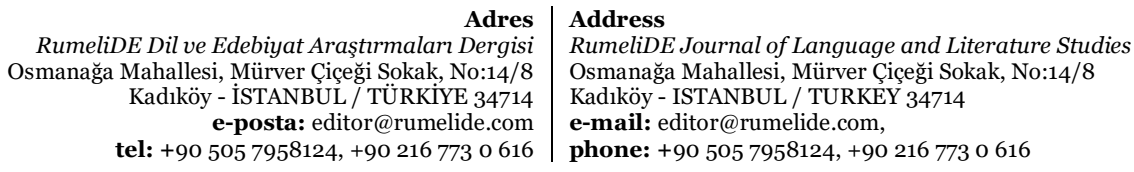




\section{Disappointment, melancholy and pain of love}

The theme of illness has an important place in terms of the development of events in Mehmet Rauf's novels. Upon the incident of falling ill or fall works as a fulcrum on which to swivel the plot on which occurs an intimacy between the man and the woman, and then confessions of love show up. It is noteworthy to mention that in the novels examined, it is mostly the male characters who suffers from love, struggles with obsessions caused by love, comes to the point of madness with the idea of betrayal, falls ill with sadness, and spends nights in fever. Female character is the element that psychologically wears out the male character and causes him to burn in love fevers. One notable exception can be the novel Heart of a Young Girl in which the female character is the one who falls to bed from pain of love and disappointment.

The novel Garâm-ı Şebâb, includes the actions occurring in a love it is told that the poet Memduh, who settled in a village by the coast on the Anatolian Side to write a poem with high literary value, enchanted by woman he saw from afar during his regular country walks and the memorable days they spent together ended in disappointment and disillusion. For him, love is a divine feeling, and he desires to be with a woman he can fall in love with. Memduh has not come across a woman worthy of merit, and he is looking for divine, heroic, distinguished and exquisite women. Finally, Memduh come across the woman he was looking for while walking around the deserted countryside. As nature with its powerful and mysterious forces occupies an important place in the search of love and perception of male character, woman is materialized as ideal one just like the dominating character as nature. The feelings of Memduh towards a woman he meets every day and sees from afar are as states by Mehmet Törenek: "When he sees the loneliness and orphanage of this woman, whom he knows on his tours to contemplate the beauties of nature, his feeling of compassion turns into love." (Törenek, 1999: 71) Love and poetry are the contents of the conversations between Memduh and this nameless woman. The female character is in favour of keeping this relation on emotional extent. Although the female character gratefully, maintains this relation an emotional basis, romantic attachments may be but need not include sexual qualities.

Memduh Bey starts kissing the hands of the female character unexpectedly during a walk. Despite the woman's protest, he does not stop kissing. The female character is disturbed by this incident, and leaves Memduh and gets back to her mansion. Three days after this incident, Memduh, longing to go to the mansion and see her, was told that the lady was sick. The ailment from which she suffers is never named, but the female character does not go to the presence of Memduh. A few days later, on a rainy day, the woman shows up in Memduh's house. "She [is] in a bout of severe fever." (p. 185) Observation showed that an attempt for a physical approach can lead to misery on her side, her reclamation provides an explanation for her position as sufferer and Memduh is deeply affected by her despair appearance: "Why did you go out? Don't you know that in this state, after coming out in this rain... But this will kill you, poor..." (p. 186) Encounter with her give him a deep shock, and her influence appears in the shape of Memduh's returning back to Istanbul.

In the novel Ferdâ-yı Garâm, a love story is told between Macit and Sermet based on the idea of loving till the end. Sermet is the female predominant character of the novel who swivels the course of the events and the thoughts of the male character Macit on life and love. Sermet's pessimistic mindset and abstraction from the real life by bringing love to a utopian position causes Sermet and Macit to walked by side to death together at the end of the novel. Sermet is an eighteen-year-old girl in deep melancholy. She has a meditation of dying in peace only when she achieves something tirelessly or hastily. According

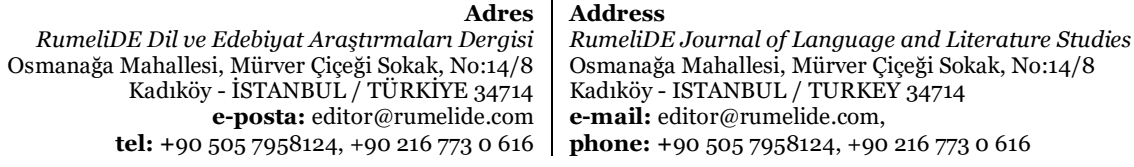



630)

to Sermet, divine notion of love is condemned to be stained. For the purpose of protecting love as recognition combined with virtue and loyalty, it requires above all else venerates love in its most perfect form while leaving space for lovers to imagine this perfection in their own ways- which means leaving the self behind. Sermet and Macit are the representators of the melancholic and pessimistic characters of Servet-i Fünûn literature with their view of this life and love. Melancholy is "a state of profoundly painful despair, loss of interest in the outside world, loss of the capacity to love, inhibition of activities, and a decrease in self-esteem, resulting in self-reproaching and delusional anticipation of punishment." (Uslu and Berksun, 1993) However, in his work Anatomy of Melancholy, which wrote in 1621, Robert Burton, stated that among the diseases related to the brain, those related to the structure of the brain were "insanity, lethargy, melancholia, madness, poor memory, deep sleep, insomnia, awake coma" (Burton, 2017: 84). Madness and insanity differ from melancholy, which is traces up in silence, in aspects such as the severity, harming the environment, and having tantrums. According to Burton, melancholy as a tendency is all states of grief, need, illness, affliction, sadness, passion, anxiety, stagnation, and nervousness that occur in a state of mental illness, restlessness, or being stuck on a thought (Burton, 2017: 99). From this point of view, it is seen that Sermet is in melancholy because of defiling and losing her, although she has not had any love affair yet. She does not enjoy the activities in daily life. Even when Sermet dreams about her life, she cannot think of a happy ending. Even her dreams end in death:

"Do you know what kind of life I sometimes imagine for myself: A short, short life... Oh my God, it's so short (...) 'it's only twenty years old!'(...) to go extinct with a subsequent death or to die while being happy... So much so that when death draws me to its embrace, my body trembles with the joys of this bliss..." (p. 41)

When Macit hears Sermet's feelings towards life, he encounters a Sermet that he never anticipated. Sermet does not enjoy the conditions in which she lives. In this novel, very gripping determinations have been put forwarded about femininity. For example, Sermet attributes this sensitive and melancholy state of her to being a woman:

"You know, if I wasn't a woman, maybe I would be happy. Because being a woman is like being ugly among women (...) And who knows how many times every woman will fall for an ugly woman fortune in her life, right? When we think that we are loved, what do we have but to feel that everything is over, that we are now removed from this heart that we have filled, that we are forgotten? Ah, this future... Here is the fate of women! What kind of patience should there be in your heart to be condemnation to one day not be loved while being loved? I'm in pain just thinking about it. (...) That's why I don't want to be a woman, and men are not obligated to commit like women; whereas women...” (p. 43-44)

She categorizes women in relation to "beauty and abject" and presents references to their life - and these less-than-lovely lady image can demonstrate the perception of society on ugly women. She has the opinion that they are almost doomed to be miserable. Another reason for Sermet's dreariness is that the man has the authority to end the relationships. Although Sermet has not had a romantic relationship with a man yet, she thinks that the relationship ends in disappointment for the woman. Macit, after listening to Sermet's sayings, attributes this emotionality, pessimism, and interest in death to the books she reads:

"What makes you this situation? It is certain that this is reading... Devoting your nights and days to your library rather than places you hate has created such a delicate feeling in you that you are tired of life

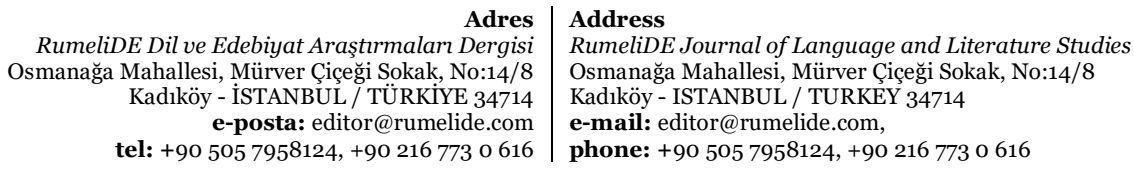


without experiencing it. However, in this state of yours, there is a lot of smell of office and living room... Your ambitions are very relative, very illusory... It's a strange kind of aspiration...” (p. 44)

Another important point in this interpretation of Macit is that the reason why Sermet is melancholic is a symptom of the intermediacy of feminen potrayal created by heartfell interests, vision of womanhood and feminine expectations. At the beginning of the novel, Sermet, who is drawn as a young girl who follows fashion magazines and spends time with other women in daily life, suddenly turns into a pessimistic and melancholic situation. It turns out that she doesn't always enjoy what she does, and that her dreams are pessimistic: "Is it a book? I can no longer find a book to read; I hate reading, writing, music, everything, I can't find anything so I think it can endow a peace of mind on my soul." (p. 47-48)

Macit, who initially finds Sermet's pessimistic thoughts about life is strange, confesses that he thinks like her as these conversations continue. He will brace the same preposition of Sermet about dying happily, saying "oh, dying is happiness" (p. 52), and an intimacy based on melancholy will take start between him and Sermet. Macit, who perceives Sermet as a daydreaming and carefree girl who does not take life seriously like other Ottoman women, will change his thoughts about her and redefine her after these conversations. At this point, we see a man subjecting a woman to external and internal evaluation:

"According to Macit, Sermet was a well-educated, well-educated creature, a bit more distinguished than all the young girls up until now; She was a bit of a dreamer, a little bit, but in fact he thought that she was equipped with a life interest unique to our women. But he suddenly saw that the spirit of Sermet had fallen into such a degree of sensitivity by sacrificing her contemplation that life would be a simple torture there." (p. 50-51)

Macit dives into deep thoughts after moving to Beykoz with his family and being alone. The yearning for a mother he experienced in his childhood affected his view of women. He could not establish a healthy relationship with women and moved away from physical contact with women for a while. The mother he dreamed of has returned to his arms, but this time he was away from Sermet. The more he thought about her, the more he realized that he loved Sermet, and as he questioned the meaning of life, he began to suffer from depression. As a result of the depressions, Macit fell ill and slept for days in fever. Love, which is accepted as a supreme form of love, becomes a source of pain, grief, and sadness for the lover when there is no possibility of reunion. The sadness and grief that the lover feels when there is no hope of reunion keeps the wound of love fresh. (Tarhan, 2014: 19) Macit, who could not open up his feelings to Sermet, had a psychological breakdown and became ill physically. The love of mother-the love of Sermet and the pain of motherlessness-the thought of not being able to reunite, the inability to confess her love and the ongoing thoughts that happiness will not last, arouse spiritual pain on Macit. With this pessimistic spirit, Macit does not want to go through a surgery and wants to die: "He was so fed up with life that when they told him about death, he said 'Oh!' with a welcoming enthusiasm.” (p. 65)

It is apparent that the female characters, who encounter an unexpected physical contact by a man, fell ill after the incident in Mehmet Rauf's novels. In the novel Garâm-ı Şebâb, we saw that Memduh unexpectedly started kissing the woman's hands, and its effect is seen upon the psyche of a woman suffering which is adjuration to the female. In Ferdâ-yı Garâm, Macit starts kissing Sermet's hands during one of these walks. Sermet stops him, but in the evening, it is learned that Sermet "suffers from a severe headache" (p. 99). As identified, women are physically disturbed at the first contact with a man.

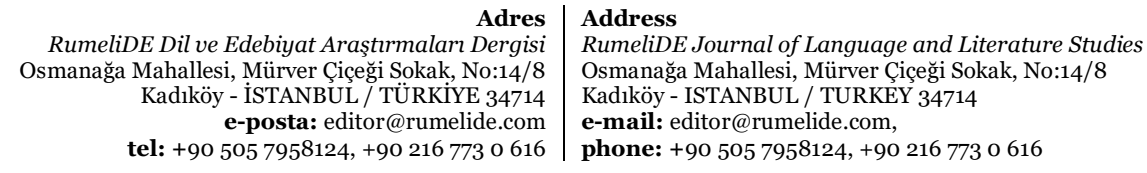



630)

In the novel September, which is accepted as Mehmet Rauf's masterpiece, Suat appears as a woman who is devoted to her husband Süreyya. Suat contemplates that in the fifth year of their marriage, her husband no longer loves her as before, and sometimes she reveals her thoughts to Süreyya that his love for herself has diminished. However, Süreyya swears that there is no such thing and says that he will die without her.

In this novel, the implication is that married women have various ailments that repercussions on their mental state. During the conversations of Süreyya and Necip, Süreyya says that symptoms such as headache or being highly strung is continuous and have their source in women nature. (s.79) Schopenhauer questions why women in many marriages have a chronic illness after a short while and why a man whose wife is sick throughout the marriage must remain monogamous in his novel called Metaphysics of Love. In addition, according to him, there is no reasonable reason why a man who suffers from a chronic disease, cannot bear children, and has an aging wife, should not take a second wife. (Schopenhauer, 2016: 24) As a matter of fact, Süreyya's wife, Suat will take on a physically sick appearance when she questions their marriage and later thinks that her love affair with Necip is over.

As Suat thinks that marriages wear out over time, she realizes that she can no longer be as happy as before. This situation triggers sickening feelings in her. She come to a point for questioning why they are not happy in their marriage like they were on the first day, puts the blame on herself, become infuriated with life itself for the feelings that change over time. Suat's sense of torment and his selfquestioning about marriage and relationships make her sick physically: "All of this naturally caused bloody struggles that were tried to be hidden under a smile and courtesy, which made her nervousness even more tired, causing long headaches, weakness, indigestion, and all of a sudden, unhappiness." (p. 112)

In many of Mehmet Rauf's works, observed many characters like Necip who sets their heart on love as in the envision in book they read but unable to find this feeling in their relationships with women in their first youth, who are heartbroken and when the relational encounters with other occurs, the urge to vent their feelings and then holding women responsible for heartbreak and undeniable despair afterwards. In terms of his failures in his relations with women, Necip resembles Macit in the novel Ferdâ-yı Garâm. What affects the lives of these young people is the unhealthy conditions of their relationships with women in their youth. As Necip gets know to Suat, he notices how superficial the women in Beyoğlu life, who look like baby doll like from the outside, are actually. Their souls are stained. In fact, the women like Suat have pure souls and they are the stunning ones. Since Necip took one of Suat's glove and hid it, he begins to suffer deeply because he can no longer open his feelings to Suat but cannot do so. Along with the pain of unrequited love and thought of what could happen after the confession of this love, Necip determines that he cannot stay in Suat and Süreyya's mansion any longer. Even Suat's call to Süreyya annoys him, "and he spent the days crying and screaming with suffering fits, saying with force of fury and in feverish mood, 'But I am dying, save me now!'"(p. 119).

In numerable works of Mehmet Rauf, the motif of male character who fell ill and fell into bed and were happy to see the woman they loved came to visit them when they were on their deathbed. In novel Ferdâyı Garâm, Sermet came to see Macit, who fell ill enough to fall into bed in his house in Beykoz, and then Macit recover. In the novel September, Necip also fell into the same situation. While Suat is making plans on how to ensure that Necip does not come to the mansion anymore, they receive the news that he "clawed death from typhoid in the vineyard for three days" (p. 129). Although she wanted to be with Necip, she was held back due to Hacer's gossip, so Suat could only pay a visit Necip in the vineyard three

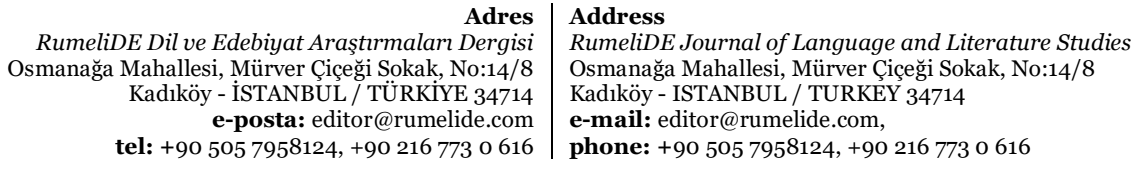


weeks later. Necip always waited for Suat during his illness and found his hope of salvation in her arrival. However, in his meeting with her, the pain of love, which had no salvation, took over again:

"He wanted her so badly, sought her so much, waited so long; He had been so busy with her that he thought that if she came now, he would be happy; but here he was, overwhelmed by the fear of feeling again that he was sick and unfortunate with an incurable disease even though she had arrived. Suad, the luminous fairy of her fiery hours, the comforting light of her malarial darkness, there was Suad, whom she saw as a faint shadow in all her illness, with her plain hair and eyes." (p.133)

In the novel September, the month of September has a great influence on the development of the storyline and also on the personalities of Suat and Necip. Suat has sense brand new feelings with the love of Necip for her, but this innocent excitement has to end due to the circumstances she is in. She is confronted with the unhappiness in her marriage and compares her experiences to the end of Summer and the arrival of September: "At that time, this period of her life seemed to Suat as evening of her own life, her own womanhood (...) Now she could see clearly what the worries and sorrows that had devastated her for a year were, and she was saying, 'Here is my September (evening)!' "(P. 171).

As Suat looks at the undergoing transformation of nature, she falls into a pessimism of how all of this happiness will end someday. There is no point in trying to be happy. Suat defines his pessimistic mood with Metaphorical allusion of "decay of men". Just as everything in nature decays and buried under soil, man will also decay. It is in vain to be hopeful and thrill. At this point, we see that Suat grapple with two emotions: Her in between pessimism on seeing that it is the end of everything, and her struggle to sprout again. However, the feeling that the Winter is inevitable after September overcomes the feelings of struggle and hope. (p. 171-172)

After moving to the mansion, we see that Suat and Necip misapprehend each other's behavior, and both thought that this love was over and personal belief of him not loving her anymore changes Suat physically and urges Necip to dream of dying. Suat weakened, turned pale, and bruised under her eyes. (p.239) Since Necip cannot accept the end of this relationship, he thinks that the best resolution is killing himself:

"Yes, he wanted to die now, since everything was over, since everything was over to this extent, he was going to die now... What an end, and how it ends, my God? (...) And there seemed to be a bloody dying savagery of vengeance beneath his feet. First of all, he fell in love with this idea, he would kill himself in front of her no matter what...” (p. 241)

In the novel The History of A Love, Güzin has come to Büyükada for a change of air from Beirut because she has a severe illness. She even presents herself to Macit as someone who is doomed to die and does not want to have a love that will harm anyone. Güzin is "an ill-fated girl whose hope has been given up by all doctors." (p.39) Although it is not known exactly what her illness is, there are no perceptible signs of her illness during night walks with Macit. The male character, Macit, has been with many women throughout his life, had short-term loves, is a womanizer person who approaches most women only for sexuality. He approached Güzin, whom everyone talked about on the island, with the desire to attain her love first, and thought that it would be a nice summer fun to live with, but when Güzin replied to his own love letters that he could not have love with anyone because he was doomed to death, Macit's understanding of love transformed from a material relationship to a spiritual relationship. After his love for Güzin, Macit realized that everything he lived with women was actually a lie and he had never tasted

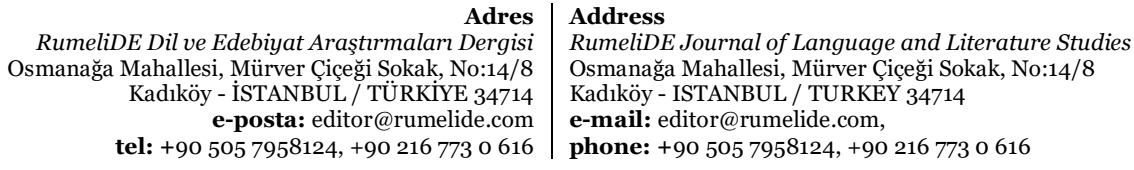


The effects of disappointment, melancholy and pain of love on the characters in Mehmet Rauf's novels / F. Ferhatoğlu (pp. 619630)

love. All the women he was with deceived him saying they love him, but their relationship ended in frustration. In the beginning, as he approached other women, he only wanted Güzin and love follows later. (p. 34) Macit's definition of love consists of three stages: A victory over the woman after the painful (agonizing) hours of waiting for the answers and reactions from the woman, and finally the woman's surrender to the man. In other words, according to Macit, love consists of surrender that first destroys people and then comes with victory. (p. 37) The depiction of Macit on effect of love on people is also foremost at this point. The person in love cannot think rationally and only listens to their feelings: “(...) Do the poor people, who have fallen into the storm called love, have any reason, idea, reasoning or logic left? Man remains stunned and animal. Idea, reason, reasoning, everything is destroyed, and people are left with a lonely feeling." (p.67)

Since the day Güzin returned to Beirut, Macit experiences a great mental breakdown as he was abandoned: "In the first days I was stunned, I could not think, I could not rest; like a sick, wounded limb, I was numb only with fever, with the feverish sadness of separation." (p.70) When he regains consciousness after fifteen days, he is surprised that he is not dead. Due to the great love he has for Güzin, he locks himself up at home and does not see anyone, including his friends, for seven months. On the day Necip arrives, he learns that Güzin has come to the island again, and his depression increases. Even though he knows that there is nothing between them and that it will hurt, he wants to whine and wail to experience that love again: "My soul is full of blessings with everything... It overflows... Still, I still want to love, I want to love, to be loved, to suffer, to cry, to die and to kill... I can't stand this beautiful life and spring, this memory... I want to cry, wail, go wild... And for her ... Just for her ...” (p.74)

Heart of a Young Girl novel stands apart from other novels with its narrator being a woman. We see a woman's thoughts on love and marriage and the place of women in the life of the period in Pervin's diary. Since it is designed in the form of a diary, Pervin writes sincerely what comes from her heart and evocative subjects as if she were having trouble. Pervin, as a representative of young girls, is an interpreter of the thoughts of all young girls about loving and being loved. Pervin liked the ideas of writer Mehmet Behiç, who came to her uncle's house, on various social issues such as the place of women in social life, the entertainment life of Istanbul, and the clothing reforms. Then, under the influence of Behiç's poems she read, she thinks that he is a very gentle and sensitive man, and she dreams of making a life with Behiç. The illness is used as a tool for Behiç and Pervin to make a confession of love to each other, although they have been together for days, but there is no conversation about love between them. Pervin, who said she was feel a little malaise, did not go down to the hall and preferred to rest in her room. Behiç, who came to their house, was told that Pervin was sick. Walking around the balcony, Behiç confesses to Pervin, who he sees from the window, that he is worried about her illness, but is relieved when he sees that she is well. (p. 152) At the end of the novel, the state of illness that comes with disappointment appears. Faced with the facts and learning that Behiç does not intend to marry her, Pervin lies ill for three days, almost like a dying person on his deathbed. (p. 156) Due to the injury of her soul, she became ill and exhausted. She thinks that she will feel this pain for months, maybe years.

In the novel Carnation and Jasmine, what happened in the love triangle between Nevhiz-Samim-Pervin and the results of this relationship are told. After returning to Istanbul from Switzerland, where he lived for many years, Samim attends a tea party held at Kadri Pasha's mansion in Nişantaşı. He sees his friend Pertev's single sister Pervin and his older brother Sadri's wife Nevhiz at this tea, attended by the notable families of Istanbul. While Samim has toing and froing on Nevhiz and Pervin, who was impressed with at first sight, we see that he has an understanding of love that is at the level of sickness. On the one hand, he desires Nevhiz, but he cannot get away from Pervin and gives her hope. According to Samim, trying

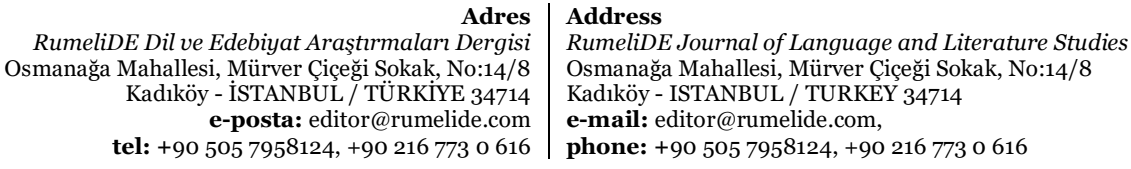


to achieve Nevhiz gives him pleasure mixed with pain: “(...) Here Pervin was ready and easy for him too... But he did not believe in such easy and simple bliss, he took pleasure in chasing, struggling, and bleeding with happiness, which are sonorous, ambitious, be oppressed with tears and sorrows." (p.69)

Samim decides that Nevhiz is different from other women when it comes to love. Underneath her cold and distant attitude, he imagines a woman "who makes him happy by burning, killing, and suffering" (p. 76) and liken himself to a fan who deliberately chooses to burn himself, thinking of the love he will live with this woman. Samim's love for Nevhiz brings with him the idea of gaining her and having her body. In response to the feeling of love, which can be called the orientation of the heart to the loved one, the tendency of the sensual to the opposite sex, in other words, the state of predominance of lust is defined as enthusiasm. (Tarhan, 2014: 36) Samim expresses his feelings towards Nevhiz as love but cannot get the idea of gaining her body out of his mind. This dilemma makes Nevhiz an object of desire and devastates Samim.

The absence of the woman in love with the excuse of illness, as in the Heart of a Young Girl, in the novel Carnation and Jasmine, has been fictionalized as the beginning of the way for the characters to confess their feelings. Nevhiz got wet by being under the rain during their walk in the grove in Akbaba. On the same night, she does not go down to dinner on the grounds that she is uncomfortable. In the morning, Samim sees that her face is yellow and red in waves, and her eyes are dim. She tells Samim, who says he is curious about her, that she went down to the hall because she knew this. (p. 111) After this first whispered conversation, confessions come follows and a relationship begins between them.

Pervin thinks that it is not possible to live with this pain and wants to die from the moment she sees Samim and Nevhiz making love at the house in Moda. The idea of "(...) dying in front of her eyes, seeing her ruined and miserable" (p.311) takes over Pervin's thoughts. One day, when she is experiencing toing and froing on between the idea of dying and leaving Samim to Nevhiz, she receives a telegram from Samim that he is sick and sets out to go to him. She goes to Moda from Feneryolu on foot under heavy rain. Because of this telegram that Samim sent to deceive her, Pervin, who went out and walked for hours under the rain, fell ill. It is said that she caught a severe pneumonia. (p. 341) Pervin could not overcome the disease and passed away.

The Last Star is distinguished from other novels by its large cast of characters and by talking about the developments in the lives of the characters in the novel Carnation and Jasmine. What happened between Fahri Cemal-Perran-Fuat İlhami is told from the perspective of three characters. While Perran, a young and very beautiful woman, is with Fahri Cemal, who is much older than her, she meets her first love, Fuat Illhami, at a ball and her whole life changes. Perran found the love, compassion, sincerity, care, protection, and money she could not find from her husband in Fahri Cemal, one of the richest in Istanbul. However, with Fuat İlhami's memory of the clean and pure love he experienced in his youth, Fuat's faithfulness to this love throughout his life and when he found Perran, he opened up these feelings to her, revealing feelings that Perran had not felt for years. Perran has everything thanks to Fahri Cemal, but "love" is missing. He finds pure love with Fuat İlhami. Perran, who is torn between the prosperous life offered by Fahri Cemal on the one hand, and a life full of love offered by Fuat İlhami on the other, decides to choose love.

When Fuat İlhami finds Perran, which he has been looking for for years, he realizes that the happiness he experienced will be short-lived/end due to Perran's departure abroad, and he tells Perran that he will commit suicide on the dock while the ship is leaving. Fuat's frustration, who has been looking for his

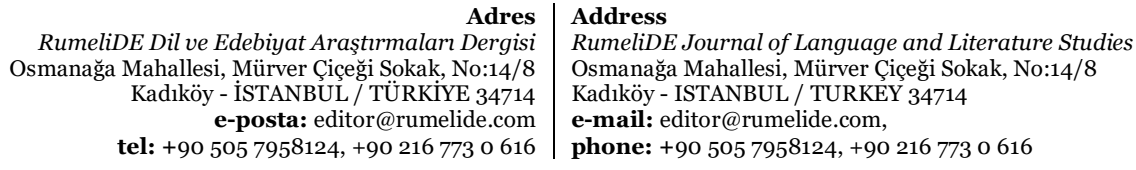



630)

first love Perran all his life and dreaming of the day he will find her, turns into a sick thought. He will not be able to live without Perran and he would rather die than lose Perran to the second. When he reciprocates his feelings in Perran who fearing his determined nature of committing suicide, he gives up on this idea.

The theme of illness related to the pain of love appears with the embodiment of Perran in the novel. She falls into a depression because of the regret she feels for choosing to live a luxurious way with Fahri Cemal - away from him when she could only think about Fuat and be happy with Fuat in Naples. She cries in her bed at night and says that she does not feel well when she wakes up in the morning: "I am not well (...) I think tonight, the fever came, I was disturbed until the morning." (p. 344) However, Fahri Cemal is aware of what happened and says that Perran's illness and insomnia he thinks that she is from the "love wound" (p. 344).

Fahri Cemal and Fuat Ilhami had the idea that one of the characters who accelerated the course of events in Mehmet Rauf's novels did not feel well and was upset. Fahri Cemal, who did not call Perran for a few days after returning from Italy, tells Perran that he has a malaise in his body and a fever. Then, Perran goes to see him. However, on the same day, when Perran leaves his, he follows her and realizes that she is going to meet Fuat İlhami. Likewise, when Perran could not reach Fuat İlhami from his office many times, she learned through Gülter that he had not been to work for a few days because he was ill and arranged a meeting with him. Fuat İlhami, after learning that Perran was Fahri Cemal's mistress at Hidayet Hanım's tea party, was writhed with fevers and realized that feeling malaise " (p. 466) when he woke up in the morning that he could not get out of bed. What was said about the woman he loved, spent his life looking for her, and promised to be his own, destroyed Fuat İlhami's nerves, injured his soul, "the long hours he spent at home in bed devastated him with the discomfort of his presence and the inflammation of his soul." (p. 467) As can be seen, the emergence of the relationship between PerranFuat Illhami-Fahri Cemal was provided by the fact that the characters became ill.

After being accused of being an immoral, fallen, and deceiving woman by Fuat İlhami and Fahri Cemal, Perran realizes that she is all alone in this life. Confronting the two men in her life has devastated her nerves. She feels that the whole life she is used to is slipping under her feet and she decides that the only way out for herself is death. According to Perran, dying means that "the endless sufferings she will suffer and the endless disasters she will see also end" (p. 544). After leaving Fahri Cemal's house, she walks to the tramway, jumps in front of an oncoming tram in a nervous breakdown and depression. With the tram stopped on time, Perran survived the accident with minor injuries and stayed at Fahri Cemal's house during the treatment process.

\section{Conclusion}

Mehmet Rauf, one of the predominant writers of Servet-i Fünûn Literature, brought sixteen novels, twelve storybooks (about 140 stories), five copyright plays, eleven translated plays and nearly sixty prose poems into Turkish literature. The main center of Mehmet Rauf's works, which he wrote with a narrative that goes down into the emotions of the individual and presents his psychology to the reader, is the woman. He touched on many subjects such as the male protagonist's thoughts on love, painful suffering at the end of love, the obsession with betrayal, the perception of women, and the sanctity of the family from the male narrator's point of view. In his works, the theme of love has been discussed in terms of its effect on human psychology. While the male narrator's point of view is mainly towards the women and present in the text, there exist also analyzes on the basis of women's the driving force that urges women 
to act in a specific way. In his works, there stands a narrator who tries to apprehend the underlying motives for the betrayal of the woman. In almost every one of his books, the reader come across with a male narrator who is in love with the notion of love and cannot do without it and continuously searching for it. The fact that women are emotionally weaker than men and some physiological and psychological needs lead them to deception in their marriage.

Comparisons on the archetypes of women such as angel of the house and femme fatale woman, are also seen in The Tanzimat (Reform) Era novels also set in Mehmet Rauf's works as well. A woman that is devoted and submissive to her husband and doesn't have an affair with another man, give sense of the ideal woman- angel. Contrary to this, emerges the concept of "femme fatale" who is described as having the power to allure man by her beauty and charm and then leave them to desperate suffering, therefore treated as the other".

However, due to complexities of love, men seem to have stilted profusion of emotion for the loved one and with the help of these reflections, they aim to invoke touching emotions on these women while the effort stands marked in contrast.

Love is central to almost all of Mehmet Rauf's works (except for a few stories about soldiery and heroism). His characters are captivated with the beauty around them, they are especially in love with the notion of love itself. Generally, they have been in a relationship with a married woman in their first flush of youth, they had their first experience of love, and they were wounded from this relationship. Love wound or heartache has affected their perspective of women throughout their lives. Love exists with dependence on passion and pain. No matter how much love hurts they can't have enough of it, so it holds a special place in the lives of characters. On the other hand, women are filled with the desire of experience of love. Instinctively, appreciation, being paid a compliment, adored by man is foundational for women. Nature and music have a provocative effect the arousal of love.

Illness makes an appearance as a preliminary factor and is in use of initiating the relationship between two sides. Men's unrequited love for the female characters, led him to find himself in distress and it is a recurring theme within these works. When being unloved by men, women seem to be on the point of a nervous breakdown, wanting to escape from their despair, they decide to commit suicide. The destructive and painful aspect of love negatively affects people's psychology.

\section{References}

Burton, R. (2017). Melankolinin Anatomisi. Cev. Merve Tokmakçığlu. Istanbul: Aylak Adam.

Karabulut, M. (2015) Tevfik Fikret Ve Cenap Şahabettin'in Ş̣irlerinde Melankoli. Turkish Studies Volume 10/2 Winter, 507-520.

Mehmet Rauf (1331 [1915]). Bir Asskn Tarihi. Istanbul: Kanaat Matbaası.

Mehmet Rauf (1925). Eylül. Istanbul: Orhaniye Matbaası.

Mehmet Rauf (1329 [1913]). Ferdâ-yı Garâm. Istanbul: Muhtar Halid Kütüphanesi.

Mehmet Rauf (1997). Genç Kız Kalbi, Istanbul: Arma.

Mehmet Rauf (2002). Karanfil ve Yasemin. Istanbul: Inkılâp.

Mehmet Rauf (1927). Son Yzldzz. Istanbul: Suhulet Kütüphanesi.

Özgen, Ahmet B. (2006). Karanlı̆̆m Aydınlı̆g: Melankolinin Tarihsel, Psikanalitik, Sosyolojik ve Felsefi Boyutları Üzerine Bir Araștırma. (Yüksek Lisans Tezi). Mimar Sinan Güzel Sanatlar Üniversitesi Sosyal Bilimler Enstitüsü, Istanbul.

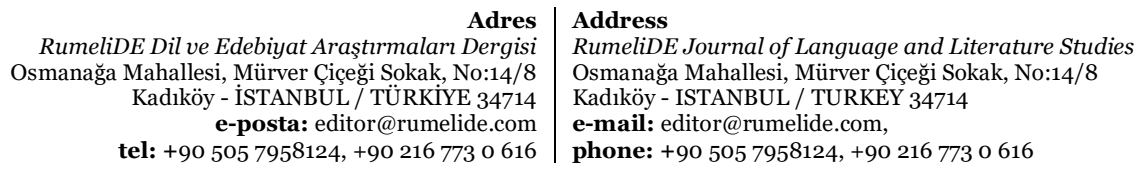


630 / RumeliDE Journal of Language and Literature Studies 2021.24 (September)

The effects of disappointment, melancholy and pain of love on the characters in Mehmet Rauf's novels / F. Ferhatoğlu (pp. 619630)

Schopenhauer, A. (2016). Așka ve Kadınlara Dair: Aşskn Metafiziğgi. Çsev. Ahmet Aydoğan. İstanbul: Say.

Tarhan, N. (2014). Aşk Terapi. İstanbul: Timaş.

Tarım, R. (1998). Mehmed Rauf (Hayatı, Sanat, Eserleri), Istanbul: Iss, Bankası Kültür.

Tarım, R. (2000). Mehmed Rauf Hayatı ve Hikâyeleri Üzerine Bir Araștırma. Ankara: Akçă̆.

Törenek, M. (1999). Roman ve Hikâyeleriyle Mehmet Rauf. Istanbul: Kitabevi.

Uslu, R. ve Berksun, O. (1993). Yas ve Melankoli. Kriz Dergisi, 1 (2).

RumeliDE Dil ve Edebiyat Araştırmaları Dergisi Osmanağa Mahallesi, Mürver Çiçeği Sokak, No:14/8 Kadıköy - İSTANBUL / TÜRKIYE 34714 e-posta: editor@rumelide.com tel: +90 $5057958124,+902167730616$
Address

RumeliDE Journal of Language and Literature Studies Osmanağa Mahallesi, Mürver Çiçeği Sokak, No:14/8

Kadıköy - ISTANBUL / TURKEY 34714

e-mail: editor@rumelide.com

phone: +90 505 7958124, +90 2167730616 